\title{
Rancang Bangun Automatic Transfer Switch Pada Sistem Charging Baterai Berbasis Kontrol PI
}

\author{
M. Irfan Zaidan ${ }^{1}$, Era Purwanto ${ }^{2}$, Syechu Dwitya Nugraha ${ }^{3}$ \\ ${ }^{123}$ Politeknik Elektronika Negeri Surabaya \\ e-mail: era@pens.ac.id
}

\begin{abstract}
Abstrak- Seiring meningkatnya kendaraan bermotor yang memerlukan bahan bakar minyak menyebabkan terbatasnya bahan bakar minyak sebagai sumber daya alam yang tidak dapat diperbaharui. Di sisi lain, banyak pencemaran udara yang terjadi di Indonesia akibat dari reaksi pembakaran bahan bakar minyak tidak sempurna yang menyebabkan adanya hasil emisi berupa gas karbon. Penggerak dari kendaraan roda tiga elektrik adalah menggunakan motor induksi 3 phasa. Metode yang umum digunakan untuk mengendalikan kecepatan motor AC adalah mengubah tegangan output dari konverter dengan cara mengubah PWM dari mikrokontroler. Alat ini menggunakan mikrokontroller ARM STM32F407VG untuk charging, dan kontrol motor menggunakan metode PI pada multilevel boost converter agar nilai tegangan keluaran sesuai dengan yang diinginkan. Sistem pengaturan kecepatan motor AC menggunakan pengendali logika PI controller, masukan (error kecepatan dan set point) akan diproses guna mendapatkan nilai duty cycle sinyal PWM, nilai inilah yang digunakan sebagai acuan pembangkit PWM. duty cycle dari pulse width modulation (PWM) maksimal yang dikeluarkan adalah bernilai $46,6 \%$ sehingga nilai tegangan keluaran yang dihasilkan $537 \mathrm{~V}$ saat tegangan masukan $96 \mathrm{~V}$.
\end{abstract}

Kata kunci: Multilevel boost converter, PI controller, PWM, motor induksi 3 phasa

\section{Pendahuluan}

Dewasa ini banyak sekali pencemaran lingkungan terutama pencemaran udara yang terjadi di Indonesia akibat dari reaksi pembakaran bahan bakar minyak tidak sempurna yang menyebabkan adanya hasil emisi berupa gas karbon yang merupakan salah satu penyebab pencemaran udara terbesar di Indonesia. Selain itu, semakin berkembangnya zaman serta semakin meningkatnya kendaraan bermotor yang memerlukan bahan bakar minyak menyebabkan terbatasnya bahan bakar minyak sebagai sumber daya alam yang tidak dapat diperbaharui akan mempengaruhi keseimbangan sumber daya yang ada di Indonesia.

Dari permasalahan di atas, penggunaan energi terbarukan (renewable energy) sangat dibutuhkan di kehidupan mendatang. Penggunaan energi terbarukan yang bersifat tidak akan pernah habis yaitu salah satunya adalah pemanfaatan matahari. Dengan memanfaatkan keberadaan wilayah Indonesia yang melintang di sepanjang garis katulistiwa, maka Indonesia mempunyai sumber energi surya yang berlimpah dengan intensitas radiasi matahari rata-rata sekitar $4.8 \mathrm{kWh} / \mathrm{m} 2$ per hari di seluruh wilayah Indonesia. Dengan menciptakan becak listrik dengan menggunakan panel surya, diharapkan mampu mengurangi polusi udara. Hal ini dikarenakan becak listrik tersebut tidak menggunakan bahan bakar minyak sehingga tidak terjadi reaksi pembakaran yang menghasilkan gas emisi. Selain itu, dengan diciptakannya becak listrik diharapkan mampu meningkatkan penggunaan becak sebagai alat transportasi umum dan mengurangi penggunaan becak konvensional yang terkesan lambat dan kurang diminati pada saat ini. Becak listrik tersebut dilengkapi dengan panel surya yang berfungsi untuk mengkonversi energi dari alam berupa energi matahari menjadi energi listrik yang dimanfaatkan untuk menggerakkan motor tersebut.

\section{Perancangan Sistem}

Perancangan dan pembuatan proyek akhir ini berpatokan pada blok diagram sistem serta alur kerja dari blok diagram. Berikut merupakan gambaran umum sistem yang ditunjukkan seperti pada Gambar 1.

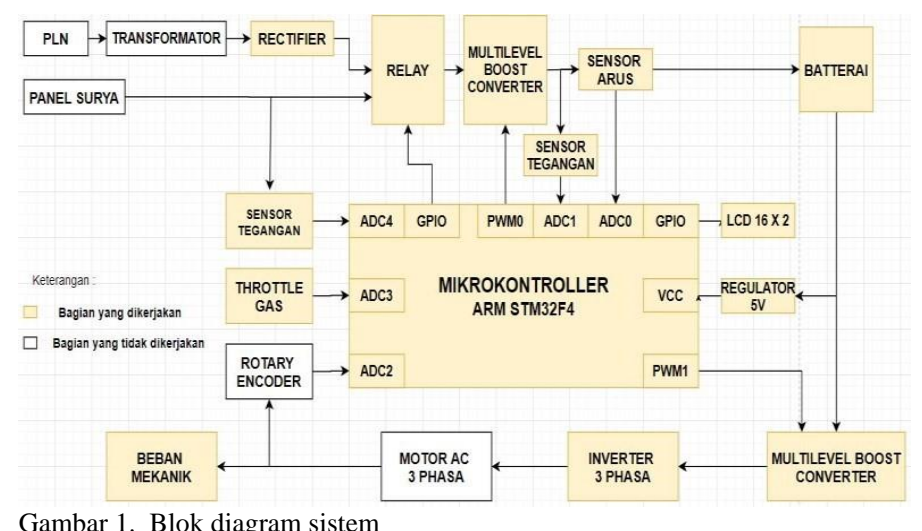

Dalam membangun sistem charging baterai digunakan kontroler dengan metode kontrol PI agar tegangan charging pada baterai konstan 57,6 V [1]. Dengan sumber panel surya dan PLN yang terhubung dengan relay yang kemudian terhubung dengan beban baterai [2]. Output daya dari solar cell atau PLN dihubungkan ke multilevel boost converter yang akan digunakan untuk mencharging baterai dengan spesifikasi 48V / 10Ah [3]. Sumber yang berasal dari baterai tidak mampu menyuplai beban secara maksimal karena dayanya yang besar dan membutuhkan tegangan yang tinggi yaitu sebesar 537 volt. Untuk menanggulangi masalah ini di sini digunakan multilevel boost DC to DC converter di mana fungsinya sebagai konverter dari tegangan DC ke DC dan menaikkan nilai tegangan dari 96 $\mathrm{V}$ ke tegangan tinggi sebesar $537 \mathrm{~V}$ (tegangan maksimal motor induksi 3 phasa) [4], [5]. 
TABEL 1

ESTIMASI DAYA BEBAN

\begin{tabular}{|c|c|c|c|c|}
\hline No & Beban & Daya(W) & Jumlah & $\begin{array}{c}\text { Total Daya } \\
\text { beban (W) }\end{array}$ \\
\hline 1 & Motor induksi 3 phasa & 746 & 1 unit & 746 \\
\hline
\end{tabular}

\section{A. Perancangan Multilevel Boost Converter}

Konverter boost multilevel adalah sebuah konverter DCDC berbasis PWM yang mengkombinasikan antara konverter boost konvensional dan fungsi switched capacitor untuk menghasilkan tegangan output yang berbeda dan stabil dengan hanya menggunakan 1 driven switch, 1 induktor, $2 \mathrm{~N}-1$ dioda dan 2N-1 kapasitor [6], [7]. N yang dimaksud adalah jumlah tingkat pada konverter boost multilevel. Konverter ini dapat dibangun dengan beberapa cara dan levelnya dapat ditambah tanpa memodifikasi/mengubah rangkaian utama [8]. Kelebihan dari topologi ini adalah:

1. Arus inputnya kontinyu

2. Ratio konversinya besar walaupun tanpa menggunakan duty cycle yang besar dan tanpa menggunakan transformator tambahan.

3. Konverter dapat menggunakan frekuensi switching yang tinggi.

Keadaan pada saat switch on ditunjukkan pada Gambar 2. Saat switch dalam keadaan on, induktor akan terhubung ke tegangan input (Vin), (Gambar 2 (a)). Jika tegangan di C6 lebih kecil dari tegangan di $\mathrm{C} 7$, maka $\mathrm{C} 7$ menjepit tegangan di $\mathrm{C} 6$ melalui D6 dan S (Gambar 2 (b)). Bersamaan dengan itu, jika besar nilai tegangan $\mathrm{C} 4+\mathrm{C} 6$ lebih kecil dari tegangan $\mathrm{C} 5+\mathrm{C} 7$, maka C5 dan C7 menjepit tegangan di C4 dan C6 melalui D4 dan S (Gambar 2 (c)). Dengan cara yang sama, C3, C5 dan C7 menjepit tegangan di C2, C4 dan C6 (Gambar 2 (d) ) [9].
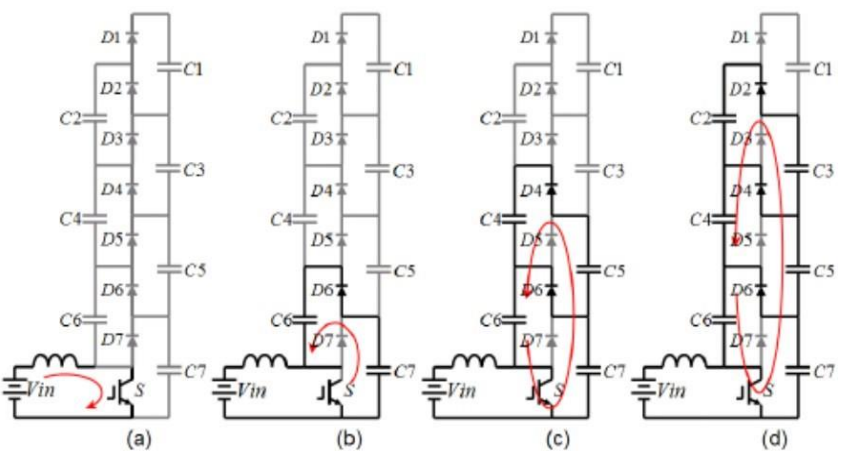

Gambar 2. Switch dalam keadaan on

Keadaan pada saat switch off ditunjukkan pada Gambar 3. Ketika switch off, arus induktor menyalakan D7 dan itu mengakibatkan semua dioda menyala. Selama keadaan off, arus induktor menyalakan D7 untuk men-charge C7 (Gambar 3 (a)). Ketika D7 menutup/menyala, C6 dan tegangan input (Vin) dan tegangan induktor menjepit tegangan di C5 dan C7 melalui D5 (Gambar 3 (b)). Dengan cara yang sama, tegangan induktor ditambah tegangan input (Vin), C4 dan C6 menjepit tegangan di C3, C5 dan C7 melalui D3 (Gambar 3 (c)). Lambat laun tegangan di C1, C3, C5 dan C7 dijepit oleh C2, C4,C6, Vin dan tegangan inductor.
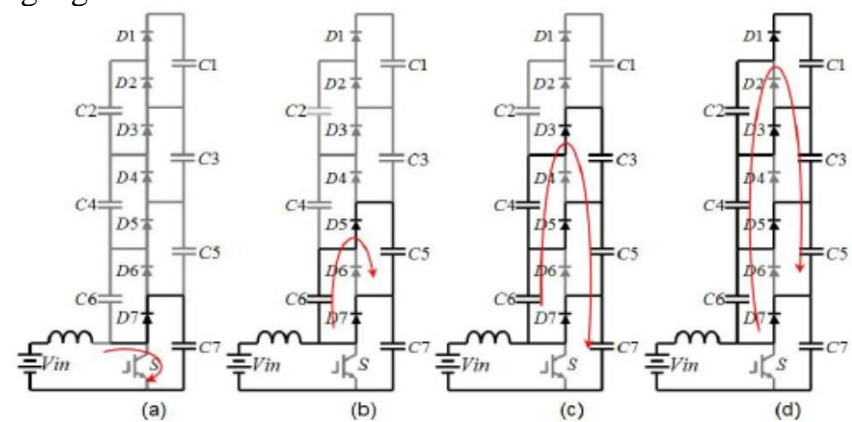

Gambar 3. Switch dalam keadaan off

TABEL 2

PARAMETER MULTILEVEL BOOST CONVERTER UNTUK CHARGE

\begin{tabular}{|c|c|}
\hline Parameter & Nilai \\
\hline $\begin{array}{c}\text { Tingkatan Multilevel Boost } \\
\text { Converter }(\mathrm{N})\end{array}$ & 3 \\
\hline Tegangan input $\left(\mathrm{V}_{\mathrm{S}}\right)$ & $12-21 \mathrm{~V}$ \\
\hline Tegangan output $\left(\mathrm{V}_{\mathrm{O}}\right)$ & $57,6 \mathrm{~V}$ \\
\hline Frekuensi switching $\mathrm{PWM}(\mathrm{f})$ & $40 \mathrm{kHz}$ \\
\hline Ripple arus $\left(\Delta \mathrm{I}_{\mathrm{L}}\right)$ & $30 \% \mathrm{~A}$ \\
\hline Ripple tegangan $\left(\Delta \mathrm{V}_{\mathrm{O}}\right)$ & $0,0576 \mathrm{~V}$ \\
& $(0,1 \%$ dari $57,6 \mathrm{~V})$ \\
\hline Induktor $(\mathrm{L})$ & $310 \mu \mathrm{H}$ \\
\hline Kapasitor $(\mathrm{C})$ & $490 \mu \mathrm{F}$ \\
\hline
\end{tabular}

TABEL 3

PARAMETER MULTILEVEL BOOST CONVERTER UNTUK KONTROL MOTOR

\begin{tabular}{|c|c|}
\hline Parameter & Nilai \\
\hline $\begin{array}{c}\text { Tingkatan Multilevel Boost } \\
\text { Converter }(\mathrm{N})\end{array}$ & 3 \\
\hline Tegangan input $\left(\mathrm{V}_{\mathrm{S}}\right)$ & $96 \mathrm{~V}$ \\
\hline Tegangan output $\left(\mathrm{V}_{\mathrm{O}}\right)$ & $537,4 \mathrm{~V}$ \\
\hline Frekuensi switching $\mathrm{PWM}(\mathrm{f})$ & $40 \mathrm{kHz}$ \\
\hline Ripple arus $\left(\Delta \mathrm{I}_{\mathrm{L}}\right)$ & $30 \% \mathrm{~A}$ \\
\hline Ripple tegangan $\left(\Delta \mathrm{V}_{\mathrm{O}}\right)$ & $(0,1 \%$ dari $537,4 \mathrm{~V})$ \\
\hline Induktor $(\mathrm{L})$ & $1,26 \mathrm{mH}$ \\
\hline Kapasitor $(\mathrm{C})$ & $90 \mu \mathrm{F}$ \\
\hline
\end{tabular}

\section{B. Perancangan Inverter Tiga Fasa}

Gambar 4 merupakan rangkaian inverter full - bridge 3 fasa yang membutuhkan 6 buah piranti switching (IGBT) yang berkerja secara berpasangan dan bekerja (on-off) secara bergantian. Inverter ini didesain untuk menghasilkan tegangan keluaran sebesar 380 Vac dengan frekuensi $\pm 50 \mathrm{~Hz}$ dan arus maksimum 15 A. Komponen switching yang berupa IGBT yang telah diatur siklus kerjanya menggunakan driver IR2111. 




Untuk mengetahui rasio modulasi amplitudo dari pembangkitan SPWM dapat dihitung dengan persamaan:

$$
\begin{aligned}
\mathrm{Ma} & =\frac{A c}{A m} \\
\mathrm{Mf} & =\frac{f c}{f m}
\end{aligned}
$$

Persamaan 1 dan persamaan 2 akan dimasukkan dalam nilai switching pada simulasi PSIM sebagai acuan nilai. Gambar 5 merupakan rangkaian simulasi dari metode switching inverter full-bridge 3 fasa menggunakan SPWM tipe unipolar.

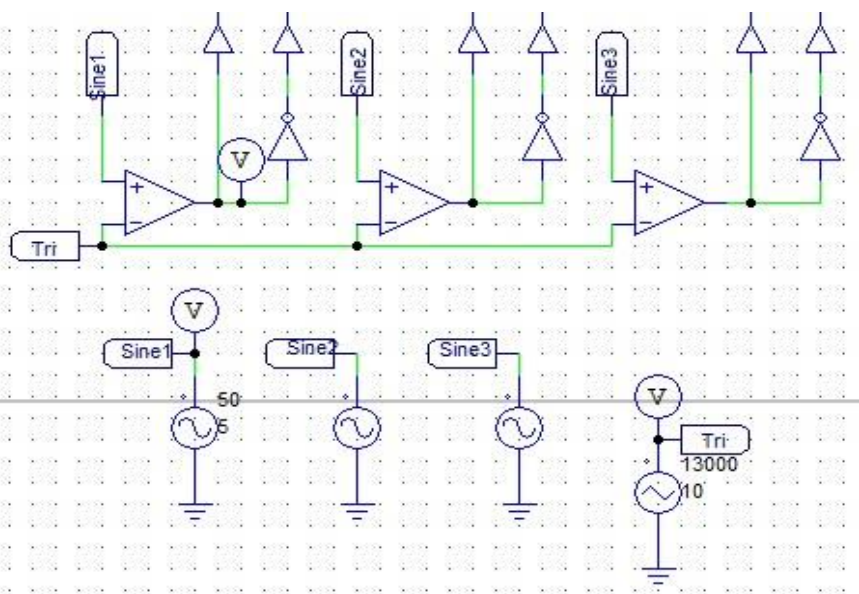

Gambar 5. Simulasi rangkaian SPWM unipolar

Frekuensi sinusoidal pada simulasi ini sebesar $50 \mathrm{~Hz}$ dan menjadi frekuensi output dari inverter. Frekuensi pencuplikan sebesar $5 \mathrm{KHz}$. Semakin besar nilai frekuensi segitiga maka semakin banyak sinyal yang dicuplik, yang akan meningkatkan kualitas gelombang sinusoidal.

Jika inverter (tanpa kontrol umpan balik) dan memungkinkan untuk menyalakan mesin induksi dari baterai atau sumber DC lainnya; kecepatan variabel juga menjadi mungkin hanya dengan mengatur frekuensi inverter. Meski begitu, performa torsinya rendah dibandingkan dengan motor DC. Tambahkan beberapa putaran umpan balik sehingga inverter menghasilkan frekuensi yang tepat yang "diinginkan" motor, dan motor induksi sekarang mampu bersaing dengan DC dan DC brushless untuk aplikasi kendaraan. Dan disisi lain konstruksi motor DC yang besar dibandingkan motor Induksi 3 Phasa.

TABEL 4

PARAMETER INVERTER TIGA FASA

\begin{tabular}{|c|c|}
\hline Parameter & Nilai \\
\hline Tegangan input inverter $\left(\mathrm{V}_{\text {Baterai }}\right) \mathrm{DC}$ & $534,7 \mathrm{~V}$ \\
\hline Frekuensi switching SPWM (f) & $13 \mathrm{kHz}$ \\
\hline Tegangan output inverter $\left(\mathrm{V}_{\text {Inverter }}\right) \mathrm{AC}$ & $380 \mathrm{~V}$ \\
\hline
\end{tabular}

C. Perancangan Kontrol PI (Proportional-Integral)

Kontrol tegangan output charging baterai menggunakan kontrol PI menggunakan dua metode, yaitu metode analitik di mana penentuan nilai $\mathrm{Kp}$ (konstanta proporsional) dan $\mathrm{Ki}$ (konstanta integral) bergantung pada nilai L(delay transportation) dan ts (time settling) dan metode trial-error di mana nilai $\mathrm{Kp}$ dan $\mathrm{Ki}$ dapat diatur sesuai dengan respon yang diinginkan [10]. Untuk mendapatkan nilai tersebut harus dilakukan simulasi untuk menilai karakteristik tegangan keluaran konverter yang digunakan. Karakteristik simulasi multilevel boost converter menggunakan simulator PSIM dapat ditunjukkan pada Gambar 6 dan output karakteristik tegangan multilevel boost converter dapat ditunjukkan pada Gambar 7.

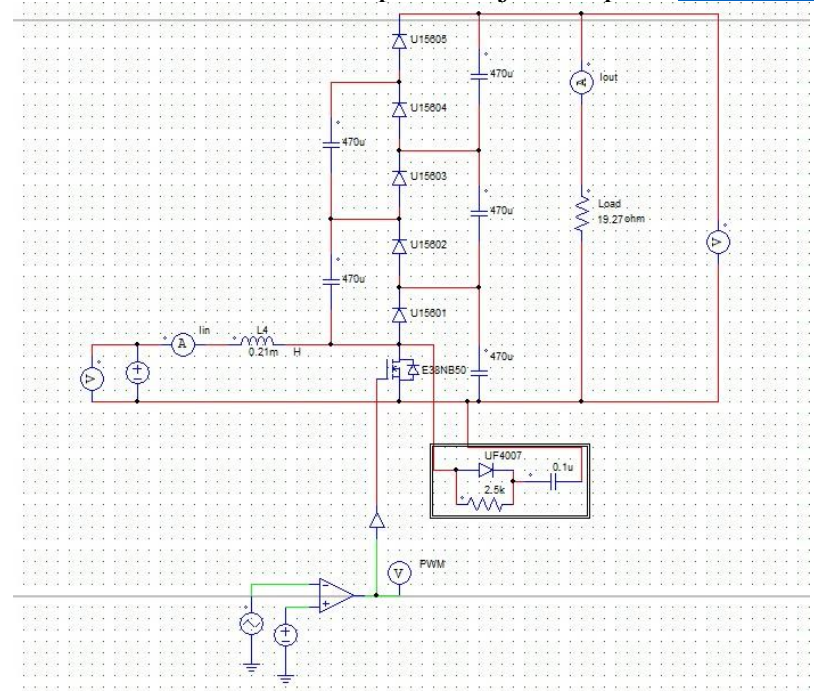

Gambar 6. Simulasi rangkaian multilevel boost converter dengan simulator PSIM

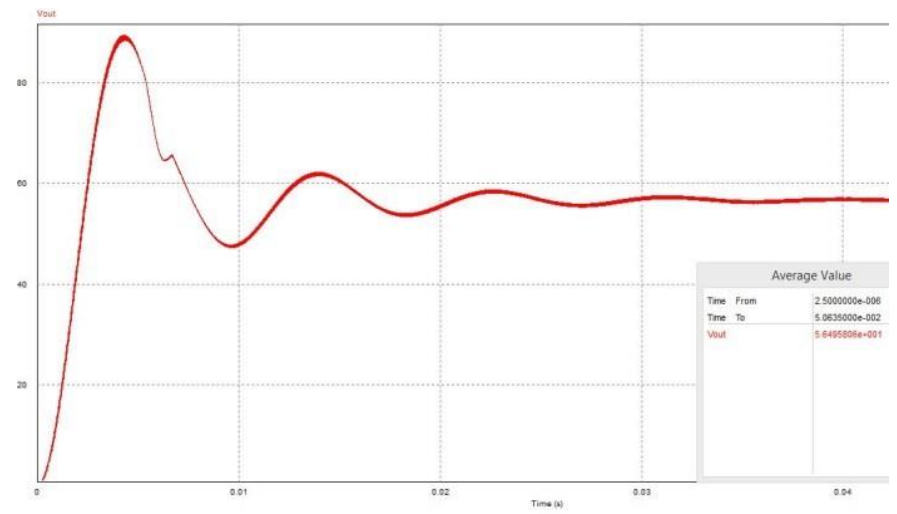

Gambar 7. Karakteristik tegangan output rangkaian multilevel boost converter dengan simulator PSIM

Submitted: 30/06/2020; Revised: 11/12/2020;

Accepted: 27/12/2020; Online first: 31/12/2020

http://dx.doi.org/10.46964/poligrid.v1i2.346 
Berdasarkan Gambar 7, untuk menentukan nilai Kp dan Ki dapat diperoleh data pada Tabel 5 sebagai berikut:

TABEL 5

PARAMETER KONTROL PI

\begin{tabular}{|c|c|}
\hline Parameter & Nilai \\
\hline Tegangan maksimum $\left(\mathrm{V}_{\text {overshot }}\right)$ & $91,4 \mathrm{~V}$ \\
\hline Tegangan setpoint $\left(\mathrm{V}_{\text {setpoint }}\right)$ & $57,6 \mathrm{~V}$ \\
\hline Time settling $(\mathrm{ts})$ & 0,03 detik \\
\hline Konstanta proporsional $(\mathrm{Kp})$ & 1,12681 \\
\hline Konstanta integral $(\mathrm{Ki})$ & 187,8025 \\
\hline
\end{tabular}

Flowchart dari Kontrol PI yang diaplikasikan pada sistem charging baterai dilihatkan pada Gambar 8 .



Gambar 8. Flowchart metode kontrol PI

\section{PENGUJIAN DAN ANALISIS}

\section{A. Pengujian Kontrol PI Multilevel Boost Converter Charging}

Pada pengujian sistem close loop digunakannya metode PI untuk menstabilkan tegangan output pada multilevel boost converter. Untuk melihat performa PI yang digunakan diperlukan pengujian dengan data logger untuk melihat respon PI pada saat transien serta saat PI terjadi gangguan. Tuning PI yang digunakan saat pengujian adalah $\mathrm{KP}=1,12681$, $\mathrm{KI}=187,8025$. Berikut adalah grafik hasil pengujian performa PI dapat dilihat pada Gambar 9.

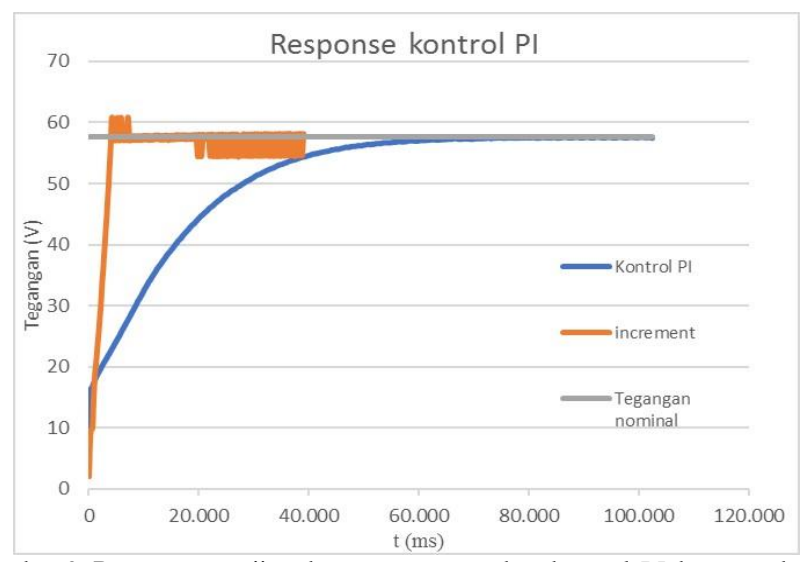

Gambar 9. Respon pengujian dengan menggunakan kontrol PI dan metode increament decreament sebagai pembanding

Setelah dilakukannya pengujian performa PI dapat dilihat bahwa metode PI yang digunakan dapat mencapai kondisi steady state yang stabil dan terlihat bahwa pengaturan duty cycle PWM menggunakan kontrol PI dapat mengurangi overshoot tegangan charging. Dalam pengujian ini juga dibandingkan nya kontrol PI dengan metode increament decreament, dapat dilihat bahwa dengan kontrol PI lebih stabil daripada menggunakan metode increment decreament dikarenakan pada metode increament decreament terdapat osilasi.

\section{B. Simulasi Multilevel Boost Converter Dan Automatic Transfer Switch Untuk Charging Baterai Dengan Control PI.}

Panel surya akan dipasang di roda tiga elektrik agar pada saat kendaraan dipakai baterai akan mengalami charge dan discharge. Sumber bisa berasal dari panel surya atau power supply sebesar $12 \mathrm{~V}$ dan output dari multilevel boost converter sebesar 57,6 V dengan beban aki untuk peng-charge-an, simulasi diatas menggunakan simplified $C$ block yang diperumpakan sebagai ARM.

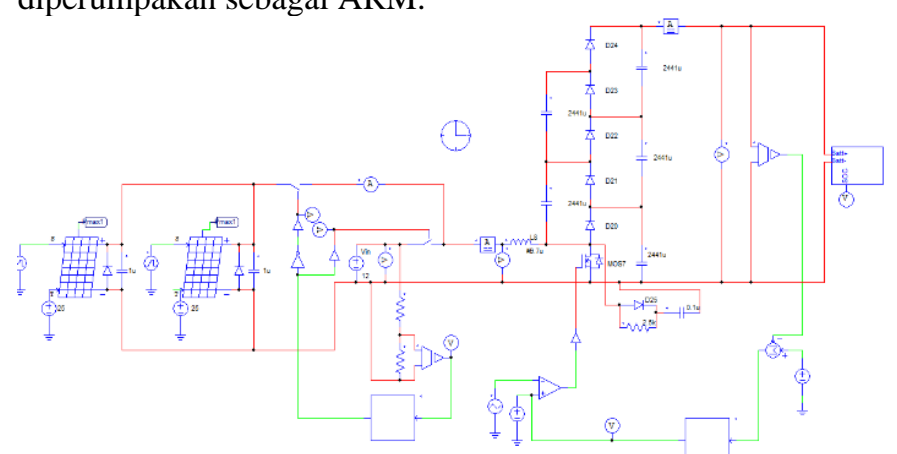

Gambar 10. Simulasi rangkaian charging close loop

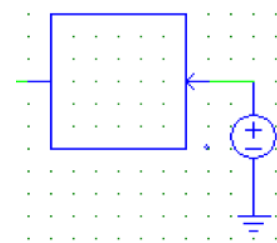

Gambar 11. Simplified C block sebagai ARM 
Berdasarkan simulasi rangkaian charging pada Gambar 10. Gambar 12 adalah hasil simulasi pembacaan sensor arus pada saat proses charging.

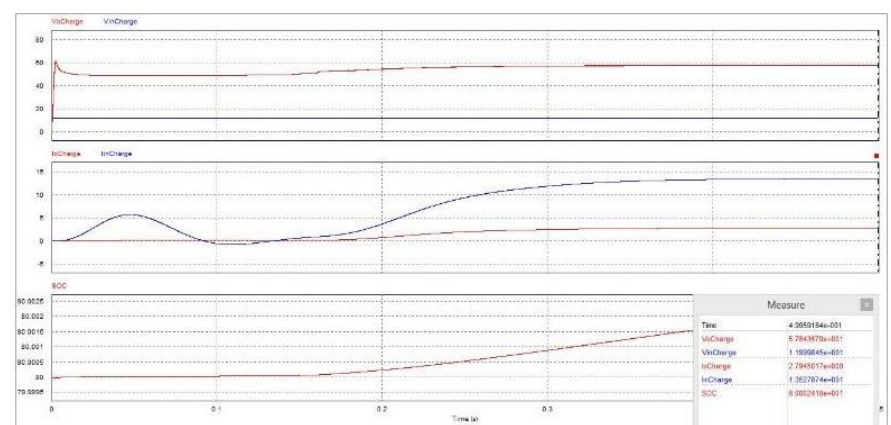

Gambar 12. Hasil simulasi pembacaan sensor arus, tegangan dan SOC pada saat proses charging.

Berdasarkan gambar di atas yang merupakan hasil pembacaan sensor arus dan tegangan saat proses charging, terlihat besarnya nilai arus charging hasil simulasi sebesar 2,79A. Pada saat dicharge, nilai tegangan pada output multilevel boost converter charge sebesar 57,6 V DC dan terlihat SOC baterai mengalami kenaikan. Dalam menentukan keandalan simulasi sistem pada close loop charging baterai maka pada pengujian simulasi ini akan dilakukan nilai iradiasi solar panel sebesar $1000 \mathrm{~Wb} / \mathrm{m} 2$.

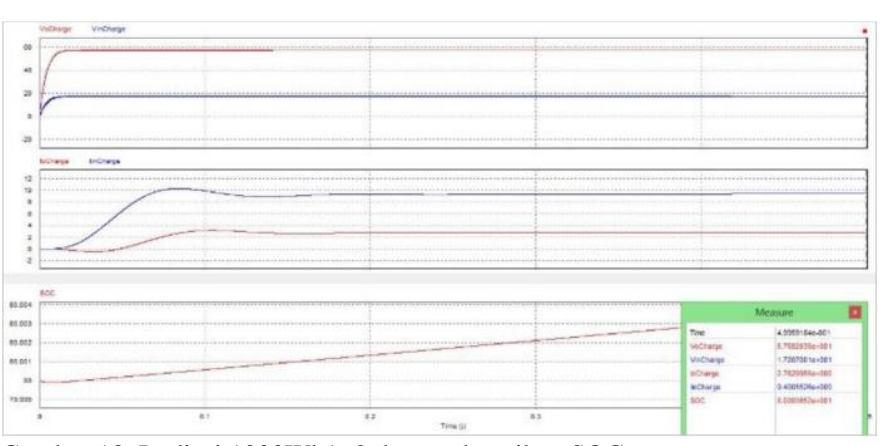

Gambar 13. Iradiasi 1000Wb/m2 dengan kenaikan SOC

Pada Gambar 13 merupakan respon tegangan output dengan sumber panel surya $200 \mathrm{Wp}$. Pada gambar tersebut dapat dilihat bahwa sistem dapat mempertahankan tegangan output $57,6 \mathrm{~V}$ dan SOC mengalami kenaikan yang artinya baterai $48 \mathrm{~V}$ 10Ah mengalami pengisian atau charge.

\section{Simulasi Inverter Tiga Fasa}

Pada simulasi inverter tiga fasa menggunakan switching SPWM untuk sistem pensaklaran pada IGBT yang digunakan. SPWM yang digunakan berjenis unipolar SPWM. Berdasarkan data parameter inverter tiga fasa pada Tabel 4, bentuk gelombang tegangan output inverter $\left(\mathrm{V}_{\text {inverter }}\right)$ dengan teknik switching SPWM unipolar dapat dilihat pada Gambar 5. Pada Gambar 14 terlihat bahwa tiap fasa memiliki perbedaan sudut 120 derajat dan bentuk gelombang output masih jauh dari bentuk gelombang sinus dengan THD (total harmonic distorsion) tinggi dengan efisiensi yang rendah. Untuk mengatasi hal tersebut dipasang filter LC untuk mengurangi harmonisa sehingga bentuk gelombang output dapat mendekati bentuk sinusoida.

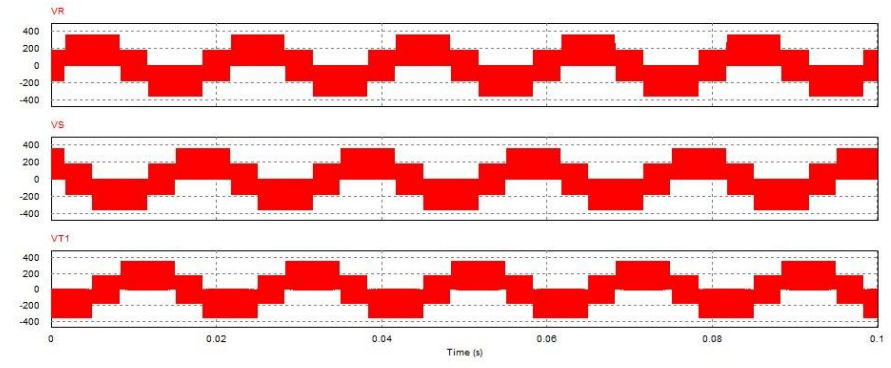

Gambar 14. Output tegangan inverter $\left(\mathrm{V}_{\text {inverter }}\right)$ dengan teknik switching SPWM unipolar

\section{Pengujian Multilevel Boost Converter}

Pengujian multilevel boost converter digunakan untuk mengetahui respon konverter terhadap perubahan duty cycle inputnya. Hal ini bertujuan untuk mengetahui perbedaan hasil output dengan perhitungan secara teoritis. Pengujian ini dilakukan dengan cara memberikan tegangan di drain MOSFET sebagai sumber dan penyulutan PWM pada gate MOSFET. Kemudian dihasilkan tegangan keluaran yang mendekati dengan tegangan yang diinginkan. Dapat dilihat hasil percobaan pada Tabel 6 dan Tabel 7 berikut ini adalah hasil pengujian multilevel boost converter menggunakan PWM.

TABEL 6

DATA PENGUJIAN NILAI MULTILEVEL BOOST CONVERTER UNTUK CHARGING

\begin{tabular}{|r|r|r|r|r|r|r|r|}
\hline Vs & Vo & Vo Teori & lo & Duty cycle lin & Effisiensi & \%error \\
\hline 12 & 69.9 & 51.4285714 & 0.23 & 30 & 1.61 & 83.21428571 & -35.91666667 \\
\hline 12 & 60 & 49.6551724 & 0.2 & 27.5 & 1.22 & 81.96721311 & -20.83333333 \\
\hline 12 & 52.5 & 48 & 0.18 & 25 & 0.98 & 80.35714286 & -9.375 \\
\hline 12 & 45 & 46.4516129 & 0.16 & 22.5 & 0.764 & 78.53403141 & 3.125 \\
\hline 12 & 39.4 & 45 & 0.15 & 20 & 0.655 & 75.19083969 & 12.44444444 \\
\hline 12 & 35 & 43.6363636 & 0.14 & 17.5 & 0.51 & 80.06535948 & 19.79166667 \\
\hline 12 & 29.8 & 42.3529412 & 0.137 & 15 & 0.435 & 78.21072797 & 29.638888889 \\
\hline 12 & 25.2 & 41.1428571 & 0.129 & 12.5 & 0.356 & 76.09550562 & 38.75 \\
\hline 12 & 22 & 40 & 0.12 & 10 & 0.293 & 75.08532423 & 45 \\
\hline \multicolumn{7}{|c|}{ NOMINAL } \\
\hline 12 & 57.5 & 49.1132333 & 0.2 & 26.7 & 1.19 & 80.53221289 & -17.07638889 \\
\hline \multicolumn{7}{|c|}{}
\end{tabular}

TABEL 7

DATA PENGUJIAN NILAI MULTILEVEL BOOST CONVERTER UNTUK KONTROL

\begin{tabular}{|l|r|l|r|r|r|r|r|}
\hline Vs & \multicolumn{1}{l|}{ Vo } & Vo Teori & \multicolumn{1}{l|l}{ lo } & \multicolumn{1}{l|}{ DC } & lin & Effisiensi & \multicolumn{1}{l|}{ \%error } \\
\hline 10 & 52.5 & 55.97014925 & 0.125 & 46.4 & 0.79 & 83.06962025 & 6.2 \\
\hline 20 & 109.8 & 111.9402985 & 0.16 & 46.4 & 1 & 87.84 & 1.912 \\
\hline 30 & 165.5 & 167.9104478 & 0.2 & 46.4 & 1.3 & 84.87179487 & 1.435555556 \\
\hline 40 & 223 & 223.880597 & 0.225 & 46.4 & 1.5 & 83.625 & 0.393333333 \\
\hline 50 & 277 & 279.8507463 & 0.25 & 46.4 & 1.7 & 81.47058824 & 1.018666667 \\
\hline 60 & 350 & 335.8208955 & 0.29 & 46.4 & 1.98 & 85.43771044 & 4.222222222 \\
\hline 70 & 388 & 391.7910448 & 0.3 & 46.4 & 2.19 & 75.9295499 & 0.967619048 \\
\hline
\end{tabular}

Dari Tabel 6 dan Tabel 7 di atas dapat dilihat bahwa konverter sudah bisa berjalan dengan baik untuk menaikkan tegangan input berdasarkan besar switching duty cycle nya. Konverter ini juga memiliki effisiensi yang cukup bagus yaitu rata-rata $80 \%$. Pada tabel di atas dapat dilihat bahwa multilevel boost converter ini memiliki perbedaan error antara teori dan praktek yang cukup besar yang disebabkan oleh beberapa faktor. Pertama, pada tabel pengujian dapat dilihat semakin kecil duty cycle maka semakin besar error yang dihasilkan. Kedua, pada multilevel boost converter ini tidak dilengkapi dengan heatsink sehingga IGBT dan Dioda menjadi panas. 
Ketiga, pada nilai komponen yang dipakai tidak sesuai dengan nilai yang didesain pada multilevel boost converter. Gambar 15 menunjukkan proses pengujian multilevel boost converter.

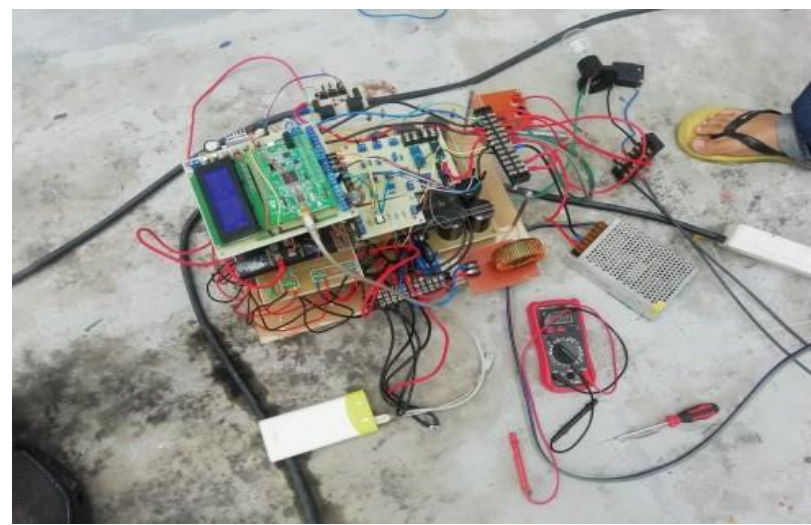

Gambar 15. Pengujian multilevel boost converter

\section{KesimpUlan}

Data hasil simulasi dan hasil pengujian dapat membuktikan bahwa kontrol PI pada saat nilai $\mathrm{KP}=1,12681$ dan $\mathrm{KI}=187,8025$ mampu memberikan respon output tegangan charging yang relatif konstan 57,6 V, dan hanya memiliki error yang sangat sedikit yakni $0,17 \%$. Sedangkan pada metode increament decreament terdapat osilasi pada respon output tegangan. Hal ini akan mengakibatkan tegangan yang tidak konstan 57,6 V. Hal ini terbukti pada Gambar 9 bahwa metode increament decreament tidak konstan $57,6 \mathrm{~V}$ dan memiliki error $4,5 \%$.

\section{REFERENSI}

[1] F.Johan, Continuous UPS pada Beban Komputer, Proyek akhir, Teknik Elektro Industri Politeknik Elektronika Negeri Surabaya, 2012.

[2] M. A. O. Eko, Supply Hybrid Sebagai Sumber Energi Listrik pada Alat Pembersih Kacang Hijau, Tugas akhir, Teknik Elektro Industri Politeknik Elektronika Negeri Surabaya, 2016.

[3] Y. Lexi, Rancang Bangun UPS untuk Beban 900VA berbasis Mikrokontroller, Proyek akhir, Teknik Elektro Industri Politeknik Elektronika Negeri Surabaya, 2011.

[4] R.Muhammad H., Power Electronics Circuits Devices and Applications, New Jersey: Prentice-Hall International, 1988.

[5] M. Sailaja, M. Spandana, Study of a DC-DC Converter with Large Step Down Voltage Conversion, Hyderabad: Malla Reddy Institute of Engineering \& Technology. India, 2015.

[6] P. Y. Hidayat, Rancang Bangun Sistem Backup PLN menggunakan Boost Converter dan flyback Converter berbasis Mikrocontroller untuk Beban Penerangan, Proyek akhir, Teknik Elektro Industri Politeknik Elektronika Negeri Surabaya, 2013.

[7] M. Z.Efendi Ir MT, DC-DC Converter, EEPIS-ITS, 2009.

[8] A. Z. Fanani, M. Ashari, T. Yuwono, "Desain dan simulasi konverter boost multilevel sebagai catu daya kendaraan listrik," Jurnal Teknik POMITS., vol. 3, no 1, 2014.

[9] P. Visnuvardhan, K. Vivek, C. Pradeep, T. K. Mohan, “A multiboost and full bridge converter for power management for hybrid vehicle by battery and super capacitors," American Journal of Engineering Research 3 (5), 2014.

[10] S. B. Yudho, H. Hikmarika, S. Dwijayanti, Purwanto, "Aplikasi perbandingan pengendali P, PI, dan PID pada proses pengendalian suhu dalam sistem mini boiler," Jurnal Amplifier., vol. 3, no. 2, November 2013.

Submitted: 30/06/2020; Revised: 11/12/2020; 